The opening session on the first evening, at which formal business tempered by interludes from a firstclass string quartette was transacted, was held in the spacious Zurich Congress House. On this occasion Naumann Medals, which are awarded for distinguished services to limnology, were presented to the American Society for Limnology and Oceanography and to the Freshwater Biological Association of the British Empire. The evening concluded with a supper, at which the Swiss organising committee were our hosts, and which served to a remarkable degree to establish contact between the different nationalities present.

The scientific work of the Congress was largely concentrated into the mornings of August 19 and 20 and the morning and afternoon of August 22. On each occasion there were simultaneous sessions concerned with general limnology and with freshwater fisheries, while on August 22 there were other sessions devoted to water utilization and water sanitation. The many short papers read at these various sessions, a considerable number contributed by the British members, covered a wide range of topics. The ecology of river-populations and self-purification in rivers, phytoplankton problems and the fungal parasites of the phytoplankton, the ecology and distribution of diverse freshwater Invertebrata, the regional limnology of Switzerland, seasonal changes at the mudsurface and detritus-drifts in lakes, fish-culture and sex in fish, the chemistry of sewage disposal waters, and the biology of filters were among the numerous subjects discussed. There were also several lectures on major topics. Of quite special interest, in view of its relation to the many lakes visited on the excursions, was the symposium on the recent development and present biological condition of the lakes bordering the Alps, in which Profs. Jaag (Zurich), Baldi (Pallanza), and Ruttner (Lunz) took part. On August 20 Profs. Steinmann (Aarau) and Willer (Hamburg) dealt with the taxonomic problems afforded by the genus Coregonus, discourses which proved of great interest even to those not directly concerned with fisheries, while on August 22 F. W. Mohlman (Chicago) gave an account of recent developments in industrial waste disposal. On this, the last evening in Zurich, the Town Council entertained the members of the Congress to dinner.

The excursions, which were designed to illustrate much of the matter that had been discussed during the scientific sessions, were excellently organised and were marked by the lavish hospitality that accompanied them. The afternoons of August 19 and 20 were devoted respectively to a visit to the Cantonal Fish Breeding Station at Stäfa, and to a trip by motor coach to various small lakes in the vicinity of Zurich. The whole of August 21 was taken up by a visit to the falls of the Rhine at Schaffhausen and to the "Untersee" (Lake of Constance), while on August 24 most of the members visited the laboratory on the Jungfraujoch. Both these full-day excursions were favoured by good weather and must have left a deep impression on the participants. On August 23 we travelled from Zurich to Interlaken via Lucerme and the Brünig Pass, making a stay of several hours at Kastanienbaum to visit the small but well-equipped hydrobiological station, originally founded by $\mathrm{H}$. Bachmann and now maintained by the Natural History Society of Lucerne. The latter very generously entertained us to lunch.

The concluding session on August 25 was held at Montreux. Dr. Gunnar Alm (Drottningholm, Sweden) was re-elected president of the Association, while Dr. Rohde (Uppsala) was elected secretary in succession to Prof. Lenz (Plön), who had filled this office since the foundation of the Congress in 1922. It was decided that the next congress should meet in Belgium in 1950, and the ensuing one in Britain in 1952 .

It is impossible to say too much in praise of the general organisation that rendered the Congress so unqualified a success, or in acknowledgment of the generosity that made so much available to the members for so small a financial outlay. Among the many Swiss men of science who were concerned, special mention should be made of the head of the Organising Committee, Dr. Huber-Pestalozzi, and of his associates Prof. O. Jaag and Dr. U. Corti, while Mrs. Minder, though never to the front, was a help and guide to all participants.

F. E. Fritsch

\section{SEMICONDUCTORS AND THEIR APPLICATIONS}

$\prod_{t h \theta}$

HE summer meeting of the Manchester and District Branch of the Institute of Physics at the University of Manchester took the form of a two-day conference on semiconductors and their applications. The chairman of the branch, Prof. E. G. Cox (Leeds), presided.

The purpose of the conference was to bring together those working on the fundamental physics of semiconductors, those making such substances commercially, and those applying them in various branches of science and engineering.

The opening session was concerned with the fundamental theory of the behaviour of electrons in semiconductors. Dr. J. W. Mitchell, of the University of Bristol, began by distinguishing between conduction in metals, in semiconductors and in insulators. In semiconductors, conductivity increases with temperature and with the amount of impurity present. The characteristic relation between conductivity, $\sigma$, and absolute temperature, $T$, is

$$
\sigma=a e^{-E / k T}
$$

where $E$ is an activation energy. Dr. Mitchell then developed most concisely the wave-mechanical concepts of electrons in ionic crystals and the conditions obtaining in periodic lattices which lead to the splitting of allowed energy-levels for the electrons into large numbers of closely spaced levels, that is, bands. The effects of the presence of defects and impurities in such a lattice were considered, and the distinctions between excess ( $n$-type) and defect ( $p$-type) semiconductors made clear. In the first type, the carriers of charge are electrons, and in the second they are 'positive holes'. For example, sodium chloride when heated to $600^{\circ} \mathrm{C}$. in an atmosphere of sodium vapour turns orange, due to the formation of ' $F$-centres', and at $300^{\circ} \mathrm{C}$. under the influence of an electric field the coloration moves towards the anode. With potassium bromide after heating in an atmosphere of bromine, under an applied field the coloration moves toward the cathode. The coloured materials behave as $n$ - and $p$-type semiconductors respectively. Much of the work on the properties of alkali halides had been carried out by Pohl at Göttingen, and Dr. Mitchell emphasized the importance of such work on relatively simple lattices in gaining an understanding of the behaviour of more complex semiconductors. 
Lead sulphide can be given semiconducting properties either by heating in sulphur vapour, in which case it becomes a defect or $p$-type semiconductor, or by heating in vacuo (giving an excess semiconductor). Barium oxide when heated in barium vapour turns orange-yellow due to the production of $F$-centres. The oxides of titanium, zine, cadmium and aluminium when heated in vacuo, and cuprous oxide, nickel oxide and uranium dioxide when heated in excess oxygen, all show semiconductor properties. Finally, Dr. Mitchell considered magnetite, a sub. stance the conductivity of which $\left(200 \mathrm{ohm}^{-1} \mathrm{~cm}^{-1}\right)$ lies approximately midway between that of a metal and of the average semiconductor. Its unit cell is twice the size of the normal cell and includes 32 oxygen ions and 24 iron ions. Of these 24 iron ions, 16 are ferric and 8 ferrous. Consideration shows that 8 of the ferric ions can be considered as 8 ferrous ions each with an extra electron, thus giving rise to additional energy-levels above the normal filled band and so accounting for its conducting properties.

Dr. R. A. Smith (Telecommunications Research Establishment, Malvern) then followed with a paper dealing principally with conductivity measurements. Previous work indicated that $a$ of equation (1) varies to some extent with amount of impurity, and $E$ varies considerably. Also there is a difference between measurements made on polycrystalline samples and those on single crystals of the same substances. Plots of $\log \sigma$ against $1 / T$ give straight lines, the slopes of which decrease with increasing quantity of impurity. In most substances, measurements of Hall coefficients and thermo-electric powers have shown that conductivity is by electrons or by positive holes. For others, notably lead and tin sulphides, conductivity can either be by electrons or positive holes, depending on whether there is excess of metal or electronegative constituent, and near the stoichiometric composition the number of carriers of each type is approximately equal. In the latter case, the conductivity is a minimum and the temperature coefficient a maximum. For polycrystalline materials conductivities range from $10^{-8}$ to $10^{-2} \mathrm{ohm}^{-1} \mathrm{~cm} .^{-1}$; but for single crystals the range is 10 to more than 1,000 , and the temperature coefficient is small and usually slightly negative. Single crystals thus appear to behave as semi-metals. The difference between single and polycrystalline materials might arise through the presence of intercrystalline barriers, and to investigate this, R. P. Chasmar has made measurements at the Telecommunications Research Establishment on evaporated layers of lead sulphide at radio frequencies up to $50 \mathrm{Mc} . / \mathrm{s}$. The results are difficult to interpret, but it appears that at high frequency the temperature coefficient of conductivity is small and negative, while at low frequency it is large and positive.

Dr. G. G. Macfarlane (Telecommunications Research Establishment) spoke about some theoretical aspects of the work done on lead sulphide cells, especially the variation of resistance at low temperature. He explained the form of the resistance-temperature curve by assuming that at low temperatures (below $150^{\circ} \mathrm{K}$.) the supply of electrons is constant, independent of temperature, but that their mobility varies with temperature.

Dr. C. J. Milner (B.T.H. Research Laboratory, Rugby) described and demonstrated various recently developed semiconductor devices useful in infra-red work and now available. A 'coolable' type of lead sulphide photoconductive cell with $10 \mathrm{~mm}$. $\times 1 \mathrm{~mm}$. element size has a detection limit (signal equal to noise for $1 \mathrm{c} . / \mathrm{s}$. band-width) of $5 \times 10^{-10}$ watt at $20^{\circ} \mathrm{C}$. and $5 \times 10^{-11}$ watt at $-80^{\circ} \mathrm{C}$. (that is, filled with solid carbon dioxide). At $20^{\circ} \mathrm{C}$., peak spectral response is at $2 \cdot 2 \mu$ and the long wave limit at about $3 \cdot 0 \mu$; at $-80^{\circ} \mathrm{C} ., 2.8$ and $3.4 \mu$ respectively. Bolometers formed of (reduced) magnesium titanate are able to detect about $10^{-6}$ watt $/ \mathrm{cm} .^{2}$; a unit with element size $2 \mathrm{~mm}$. $\times 0.2 \mathrm{~mm}$., suitable for spectrometer use, has been standardized. The sensitivity of these types of detector in radiation pyrometry is comparable for source temperatures of $100-200^{\circ} \mathrm{C}$. Nermst filaments (zirconia rods with platinum leads) operating as radiation sources at $2,000-2,100^{\circ} \mathrm{C}$. in free air were also shown.

Dr. Milner referred to the theory of Sosnowski, which explains the experimental result of Starkiewicz and others, that maximum photosensitivity in lead sulphide coincides with zero (overall) thermo-electric power, by identifying this state as that giving maximum frequency of alternation between $n$ - and $p$ regions. He suggested that the theory also associated high sensitivity with an uneven distribution of impurities, and that this might explain the wide variations encountered in processing evaporated cells.

Dr. R. W. Sillars (Metropolitan-Vickers Electrical Co., Ltd.) gave a paper on non-linear resistors, in which he dealt with the properties of silicon carbide. Polycrystalline silicon carbide bonded by clay showed non-linearity of its current-voltage relationship and other properties quite different from specimens of sintered silicon carbide. Besides demonstrating these properties he outlined methods of using such semiconductors as circuit elements.

Mr.H.Wolfson (Standard Telephones and Cables Co., Ltd.) presented a paper on thermistors in which he began by reminding his audience of the researches of Faraday on the properties of silver sulphide over a hundred years ago, and the development which has taken place up to the present time. The use of silver sulphide was abandoned some years ago because of the occurrence of polarization effects due to ionic conduction and the presence of a 'hysteresis' loop when temperature changes occur. At the present time the most common materials used are the oxides of cobalt, manganese, nickel, iron, chromium and copper. In production, beads of the oxides, mounted on fine platinum wires, are fired in controlled atmospheres. Typical thermistors have a 'half-temperature' of $20^{\circ} \mathrm{C}$. at $300^{\circ} \mathrm{K}$., that is, a temperature change of $20^{\circ} \mathrm{C}$. at $300^{\circ} \mathrm{K}$. will double or halve the electrical resistance of the bead. Another type of bead has a cold resistance of $2,000 \mathrm{ohms}$, but if 20 milliwatts is dissipated in the bead its resistance will fall to $60 \mathrm{ohms}$. The use of thermistors as circuit elements was described, as well as some of their applications in medical research as temperature indicators.

Dr. H. L. Penman (Rothamsted Experimental Station) described the development of a portable thermistor bridge for micro-meteorology among growing crops. A portable unit had been built to measure temperature, humidity and wind speed among growing potato-crops in connexion with an investigation into factors affecting the spread of virus disease.

Mr. S. L. Martin (Philips Electric, Ltd., London) described recent experiments carried out by Vink on the conductivity of mixed barium and strontium oxides, which were explained in terms of conduction through crystallites in contact and thermionic 
emission from crystallite to crystallite. The curve of conductivity as a function of temperature showed three different slopes for the temperature ranges, less than $700^{\circ}, 700-800^{\circ}$, and above $800^{\circ} \mathrm{K}$., the values agreeing with those previously reported. In discussion, the need for consideration of much simpler substances was emphasized as well as the elimination of uncontrollable variables, and it was suggested that magnesium oxide would be the easiest oxide to study since large single crystals have recently become available.

Photo-conductivity of the lead sulphide type of semiconductors attracted some discussion, especially as the literature appeared to indicate that the method of preparation of the lead sulphide films affected considerably their photo-conducting properties. It was suggested that the lead telluride type of cell should be studied since its production does not involve contamination by oxygen, etc.

The final session of the Conference was devoted to an exhibition of properties and applications of semiconductors, many of which had been discussed in the main sessions. A clutch using the Johnson-Rahback effect was shown using polished magnesium titanate in contact with polished brass, as well as a lead sulphide cell showing the high temperatures reached at hot spots at frictional contacts.

The papers and discussions made clear the growing interest in the theory and applications of semiconductors, and directed attention to the work pro. ceeding in government, industrial and university laboratories. Some of the papers presented will lead to contributions to other journals.

\section{W. Grattidge}

F. A. VICK

\section{SELECTION OF STUDENTS FOR UNIVERSITIES}

$\mathrm{O}^{\mathrm{N}}$ $\mathrm{N}$ the morning of September 14, Section L (Education) of the British Association discussed "Selection at the University Level". Mr. W. O. Lester Smith, president of the Section, presided.

Mr. J. O. Roach spoke from experience of the Civil Service Selection Board, and previously as a Cambridge tutor. He said that some well-known modern methods of selection depended essentially on a careful job analysis. But in the case of university students, for what were we selecting? For success in examina tions, for success in life, or for what ? There was no one criterion and therefore no one method of selection. $\mathrm{He}$ felt strongly himself that there must on no account whatever be any interference with those of exceptional intellectual powers; no non-academic criterion must be allowed to exolude these. Also he was against a health test-too many men of intellectual distinction had suffered from poor health since the beginning of the world. Forecasts of employability, too, were extremely difficult to make successfully. We must not exaggerate the ill-success of the present method; at least it satisfied public opinion as nonpolitical and generally fair. Still, methods of selection were certainly an important problem, now that there was hope that all, or nearly all, the boys and girls of ability in the nation would reach the sixth forms of schools; and the dissatisfaction with to-day's students expressed by Lord Lindsay of Birker in the House of Lords had met with wide agreement. $\mathrm{Mr}$. Roach emphasized that the need for a new approach was being widely recognized in the universities; and he warned the meeting against assuming that there was any one quick and easy solution to be found.

Mrs. J. L. Stocks found wide agreement among those present with views she had formed from her experience at Westfield College, London. There she had, with very small exceptions, been concerned only with honours women students for arts subjects. She thought that there was a serious danger of paying too much attention to the requirements of the various professions, and too little to the quality of life inside universities. She was herself impressed with the qualities of to-day's women students, who were drawn from a wider range than the students of the '90's, with their cultured, keen but rather narrow backgrounds. In the sixth forms of schools nowadays, the girls had done all sorts of things outside formal classes, from dramatics and foreign visits to conferences on world citizenship and the organising of national savings. They had their shortcomings, of course ; some of them, for example, had no idea how to talk to a stranger or how to go away from a party.

As for the present system of selection, Mrs. Stocks said there was rather an absence of system. The anxious queueing for Somerville, Westfield and other residential colleges was a ridiculous arrangement, infuriating for the selectors and very bad indeed for the adolescent selectees. She thought that any better method of selection would be likely to involve some degree of conflict with hitherto accepted individual liberties; but this might have to be accepted. A final solution might well take time to find, as the encouraging success of social democratic education was still a new thing. At all costs, universities must remain academic communities, and not become, for example, mere schools for leadership.

Mr. C. R. Morris spoke as a headmaster. He did not believe that the selection of individual students was the most important problem to-day, urgent as it was. The universities appeared to be dissatisfied with nearly all the students they were admitting, and not just with the small percentage of the total body who might be different if the system of selection were different. As a result, many people seemed to be toying with the idea that able boys ought to continue right up to the age of eighteen with work of the general type of school certificate work. If this were really intended, it would be a very serious mistake. It had been a great triumph on the part of the grammar schools to lead so many good students to the doors of the university and make the present university expansion possible. It must not be supposed that all able boys wanted to go to the university. Outside the professional and near-professional classes, this was far from being the case. In the other sections of society, it was the schools which had to do the missionary work, and without doubt it was by their sixth-form courses that they succeeded.

Moreover, this sixth-form work, Mr. Morris claimed, was in principle educationally sound. After reaching the age of fifteen or so, an able boy, whose contemporaries were starting on their working careers, needed to feel that he was beginning to become a real scholar or expert in the group of studies for which he had the best aptitude. This gave him his initiation into the commonwealth of learning. Certainly his work in his special field ought to have a less crowded syllabus than at present and give him more elbow room to explore for himself ; and outside 